\section{ABOUT WEAR RESISTANCE OF LINEAR BLOCK- POLYURETHANES}

\section{VOLODYMYR MYKOLAJOVYCH ANISIMOV ${ }^{1}$, ANTON PANDA ${ }^{2}$ VOLODYMYR VOLODYMYROVYCH ANISIMOV ${ }^{1}$, KONSTANTIN DYADYURA ${ }^{3}$, IVETA PANDOVA ${ }^{2}$}

${ }^{1}$ Ukrainian State Chemical Technology University, Ministry of Education and Science of Ukraine, Dnipro, 49005, Ukraine

${ }^{2}$ Technical University of Kosice, Department of Automotive and Manufacturing Technologies, Faculty of Manufacturing Technologies with a seat in Presov, Slovak Republic

${ }^{3}$ Sumy State University, Ministry of Education and Science of Ukraine, Sumy 40007, Ukraine

DOI : 10.17973/MMSJ.2020_11_2020024

e-mail : anton.panda@tuke.sk

Linear block-polyurethanes (BPU) are finding more and more practical applications in industry, and their recipe range is rapidly expanding. It is shown that the evaluation of the tribotechnical characteristics of BPU depending on hardness, as suggested by ISO 16365-1:2014 P1, is inaccurate and requires further research to establish the relationship between structure and properties of polyurethanes, taking into account their chemical structure and the type of initiaal components. The dependences of the tribotechnical characteristics of linear block-polyurethanes under friction with steel without external lubrication and in the liquid on the parameters of structural organization of the polymer were studied: at the molecular level (oligooethers, oligoesters), at the topological level (change in the molecular weight of oligomers from 500 to 2000), at supramolecular level (influence of crystallinity), at the morphological level (content of hard phase). The change in the roughness of steel counterbody during friction of polyurethanes with the content of hard blocks $20 \%, 50 \%$, and $70 \%$ was also studied. A method is proposed for increasing the wear resistance of polyurethanes by thermal diffusion saturation of the surface with silicon carbide particles.

KEYWORDS

linear block-polyurethane, wear resistance, coefficient of friction, hardness, molecular weight, content of rigid blocks, counterbody roughness, thermal diffusion surface saturation

\section{INTRODUCTION}

Modern technology development is closely related to innovations in the area of new polymeric composite materials. Polymeric composites, generally, are used as materials of construction function. An actual problem of modern technology is the necessity of materials of high wear and abrasive resistance creation [Zia 2007, Król 2007, Chattopadhyay 2009, Shtompel 2011, Madbouly 2009, Thomas 2018 ].

The actuality of such polymeric materials development is determined, at first, by economic factors: necessity of ferrous and non-ferrous metals replacement, increasing the performance of machines and aggregates, expenses reduction. Construction plastics are used for replacement of bronze and other alloys of non-ferrous metals because of their high wear resistance (slip bearings, gears, rotors, clutches, face seals, etc.). The usage of polymeric materials also offers a number of advantages: ability to create fundamentally new product designs, reduce mass of parts, reduce the noise level and increase durability, even in conditions of intensive abrasive wear and in an aggressive environment [Dyadyura 2016, Panda 2017, Duplakova 2018, Jurko 2012, 2016, Monkova 2013, Gombar 2013, Mrkvica 2012, Leššo 2010, 2014, Balara 2018, Krehel 2013, Krenicky 2012, Olejárová 2016, Panda 2011, 2013, 2018, Prislupcak 2014, 2016,Ragan 2012, Valíček 2016,]. Widespread usage of polymer composites based on polyurethanes is due to the unique combination of high level of strength and elasticity, oil and gas resistance, shock and vibration resistance [Anisimov 2019, Anisimov 2019].

The actuality of presented research is primarily determined by ecologic factors - block structure polyurethanes (blockpolyurethanes) provide a unique set of properties and, at the same time, they are recyclable, processed by waste-free technology on high-speed automated equipment.

However, development of recommendations of justification the choice of block-polyurethanes, which is optimal for these operating conditions, is empirical, and the concept of "composition-structure-properties" is incomplete and contradictory. Considerable amount of researches on block polyurethanes is highly specialized and scattered [Shtompel 2011, Madbouly 2009, Thomas 2018, Rimar 2016, Vojtko 2014, Zaborowski 2007, Straka 2013, 2014, Markulik 2016, Michalik 2014, Janekova 2014, Sebo 2012, Bielousová 2017, Dobránsky 2019, Panda 2012, Mačala 2012, Pollák 2018]. Therefore, development of scientific basis for the creation of blockpolyurethanes of high wear and abrasion resistance, taking into account the influence of the structural organization parameters of all levels of polymeric material on the properties is an urgent scientific and technical problem and is of great practical importance for usage in industry.

\section{MATERIALS AND METHODS}

\subsection{Materials}

Block-polyurethanes of different molecular structure are selected as objects of the study. Synthesis was carried out from oligomeric esters (synthesized from adipic acid and glycols of methylene series of different nature: oligoethylene glycol adipate of molecular weight $\sim 2000\left(\mathrm{OEGA}_{2000}\right)$, oligobutylene glycol adipate of molecular weight $\sim 500$ and $\sim 2000$ (OBGA ${ }_{500,}$ $O B G A_{2000}$ ), oligoethylene butylene glycol adipate of molecular weight $\sim 2000\left(\mathrm{OEBGA}_{2000}\right)$ and oligomeric ether - oligooxy tetramethylene glycol of molecular weight 1000 (OOTMG 1000 ), synthesized from tetrahydrofuran). Urethane groups were created from 4,4'- Methylene diphenyl diisocyanate (MDI), a low molecular weight glycol $-1,4$ butanediol (butylene glycol) (BD) was inserted for obtaining block structure of BPU. Blockcopolymer molecule consists from parts that differ in flexibility and repeat. Elastic blocks are formed from flexible parts (oligoeters or oligoesters). Rigid blocks are formed as a result of the self-organization of urethane groups. Molecular weight of all BPU samples is $\sim 50000 \div 70000$ (characteristic viscosity [ $\eta$ ] = $0.8 \div 1.1 \mathrm{dl} / \mathrm{g}$ of BPU in dimethylformamide).

\subsection{Methodology of research}

Molecular structure was regulated by changing the nature of oligoesters between simple and complex ones. Simple oligoesters are synthesized from tetrahydrofuran (OOTMG). Complex oligoesters were synthesized from adipic acid and low molecular weight diol of different nature: oligoester with a irregular period of identity (OEGA), oligoester of the regular structure (OBGA), mixtures of OEGA and OBGA at equimolar ratio (OEBGA). The topological structure was regulated by 
change in molecular weight of oligoether in the range of 5002000. The morphological structure of BPU macromolecule was regulated by changing the ratio of oligoester with low molecular weight diols. The number of butandiol varied from 0 to 7 moles. In this study, standard methods were used to determine the physico-mechanical characteristics, to study the structure, and also the special methods of studying the tribological characteristics [Anisimov 2019].

\section{RESULTS AND DISCUSSION}

It is known that $B P U$ based on oligoesters $\left(O E G A_{2000}, O B G A_{500}\right.$, $\mathrm{OBGA}_{2000}$, OEBGA ${ }_{2000}$ ) have higher physico-mechanical characteristics, better resistance to light and thermal oxidative degradation, are easier to process into products and have lower price. BPU based on oligoethers (OOTMG ${ }_{1000}$ ) have increased hydrolytic resistance, frost resistance, are more resistant to the action of microorganisms [Anisimov 2019]. These features of linear block polyurethanes must be first of all taken into account when developing wear-resistant parts based on them. It is also important to take into account the degree of crystallinity of both individual components as well as all block material. It is known that under conditions of intensive dynamic impact BPU of a high degree of crystallinity have a tendency to "vitrification". This leads to cracking, loss of strength and failure of critical parts of friction units of machines and aggregates (Fig. 1). High values of crystallinity are provided by an ability of a number of oligoglycols (for example, $\mathrm{OBGA}_{2000}$ ) to selforganize or hard phase formation [Anisimov 2019].

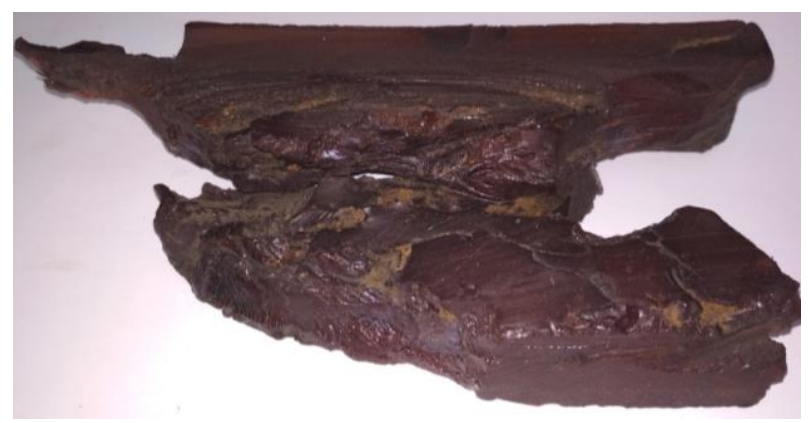

Figure 1. The characteristic "vitrification" of highly crystalline products from block-polyurethanes during exploitation under conditions of intensive dynamic impact

In our opinion, an accepted assessment of tribological characteristics of BPU from hardness or elasticity, which does not take into account the peculiarities of their molecular structure and the nature of initial monomers, is also erroneous. Block-polyurethanes of same structure but of different molecular weight or of different ability of oligoglycols to crystallize can have hardness values that differ in 2 times and, accordingly, different wear and friction coefficient values [Anisimov 2019]. Pretty much such judgments are promoted by the fact that, according to current standards, hardness values are necessarily given in the designations of trademarks of industrially produced linear block-polyurethanes [ISO 16365-1:2014]. The usage of polyurethanes gives a significant win in price when taking into account such factors as product reliability, durability and absence of downtimes, but not only the price of product. In order to determine tribological characteristics in relation to structural and exploitation parameters, the semi-industrial studies were carried out on friction machine 2070 SMT-1, according to the scheme of «shaft-partial bearing» under both non-lubrication conditions and friction in water [8]. As initial materials, BPU of hard blocks content $\mathrm{P}_{\mathrm{c}}=20-60 \%$ and molecular weight which corresponds characteristic viscosity values $[\eta]=0.8-1.1 \mathrm{dl} / \mathrm{g}$ were chosen. Previous studies have shown that the initial BPU of this structure have high deformation characteristics as well as sufficient hardness [Anisimov 2019]. They are BPU based on $\mathrm{OEGA}_{2000}$. As studied parameters linear wear intensity and friction coefficient were chosen, and as variable factors - a few exploitation parameters: sliding velocity, specific load, temperature in the contact zone and amount of antifriction filler. The intervals of variable factors for different friction conditions are given in Table. 1. Results of experiments are presented in the form of three-dimensional plots (fig. 2, fig. 3), which show that, independently from friction conditions, influence of exploitation parameters and structural factors is decisive, so they should be taken into account during modeling and calculations of machine parts of tribological destination.

Table 1. Intervals of variable factors

\begin{tabular}{|c|c|c|c|c|c|}
\hline \multirow{2}{*}{ Parameters } & \multicolumn{5}{|c|}{ Intervals of variation } \\
\cline { 2 - 6 } & $\begin{array}{c}\text { Sliding } \\
\text { velocity } \\
(\mathrm{V}), \mathrm{m} / \mathrm{s}\end{array}$ & $\begin{array}{c}\text { Specific } \\
\text { load } \\
(\mathrm{P}), \mathrm{MPa}\end{array}$ & $\begin{array}{c}\text { Tempera- } \\
\text { ture } \\
(\mathrm{T}), \mathrm{K}\end{array}$ & $\begin{array}{c}\text { Hard } \\
\text { blocks } \\
\text { concentra- } \\
\text { tion } \\
\left(\mathbf{P}_{\mathrm{c}}\right), \%\end{array}$ & $\begin{array}{c}\text { Amount of } \\
\text { antifriction } \\
\text { filler } \\
\text { (C), } \\
\text { mass \% }\end{array}$ \\
\hline $\begin{array}{c}\text { Variation } \\
\text { interval } \\
\text { under friction } \\
\text { without } \\
\text { lubrication }\end{array}$ & $0-2$ & $0-1$ & $273-400$ & 40 & $0-40$ \\
\hline $\begin{array}{c}\text { Variation } \\
\text { interval } \\
\text { under friction } \\
\text { in water }\end{array}$ & $0-3$ & $0-9$ & 300 & $20-60$ & - \\
\hline
\end{tabular}

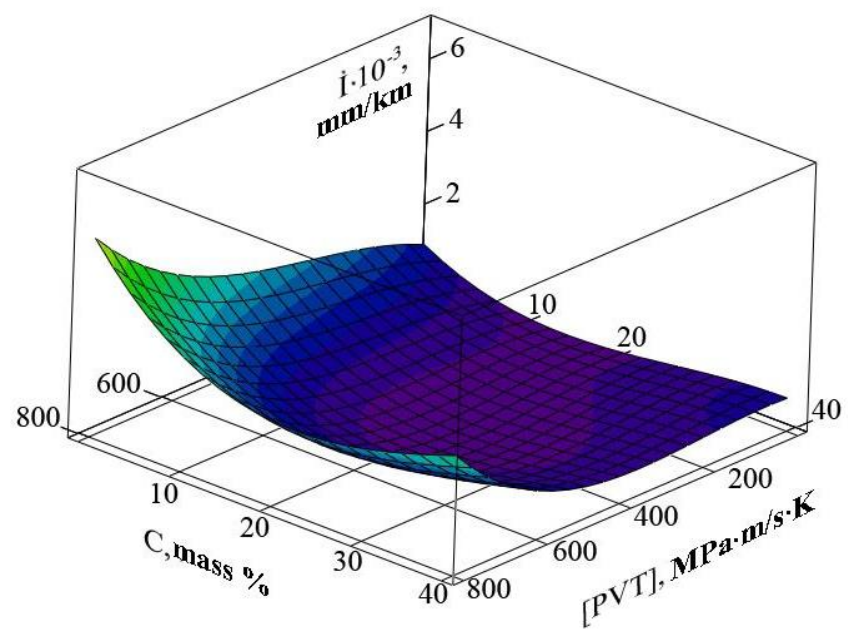




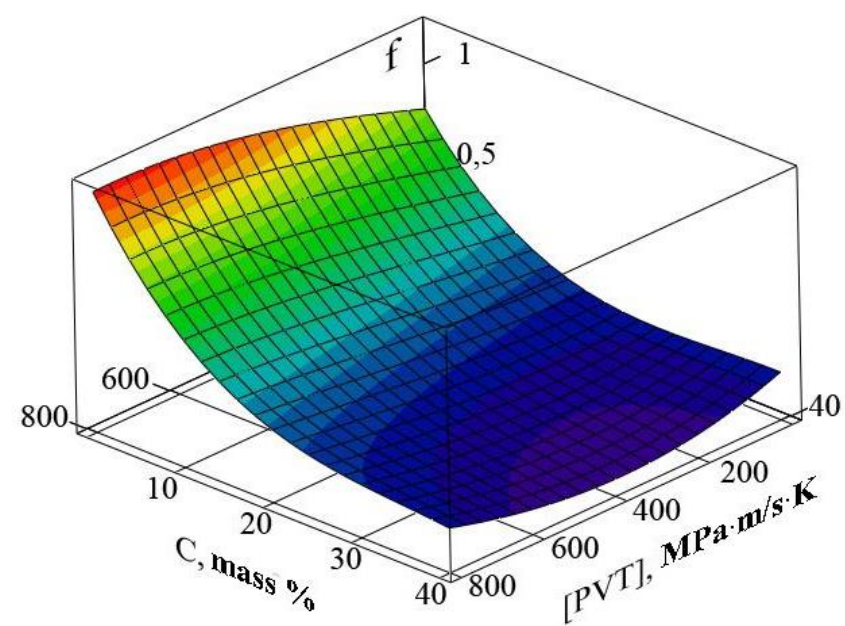

b

Figure 2. Dependencies of wear intensity (I) (a) and friction coefficient (f) (b) of BPU on exploitation parameter of usability [PVT] and amount of antifriction filler (C) under conditions of friction without lubrication
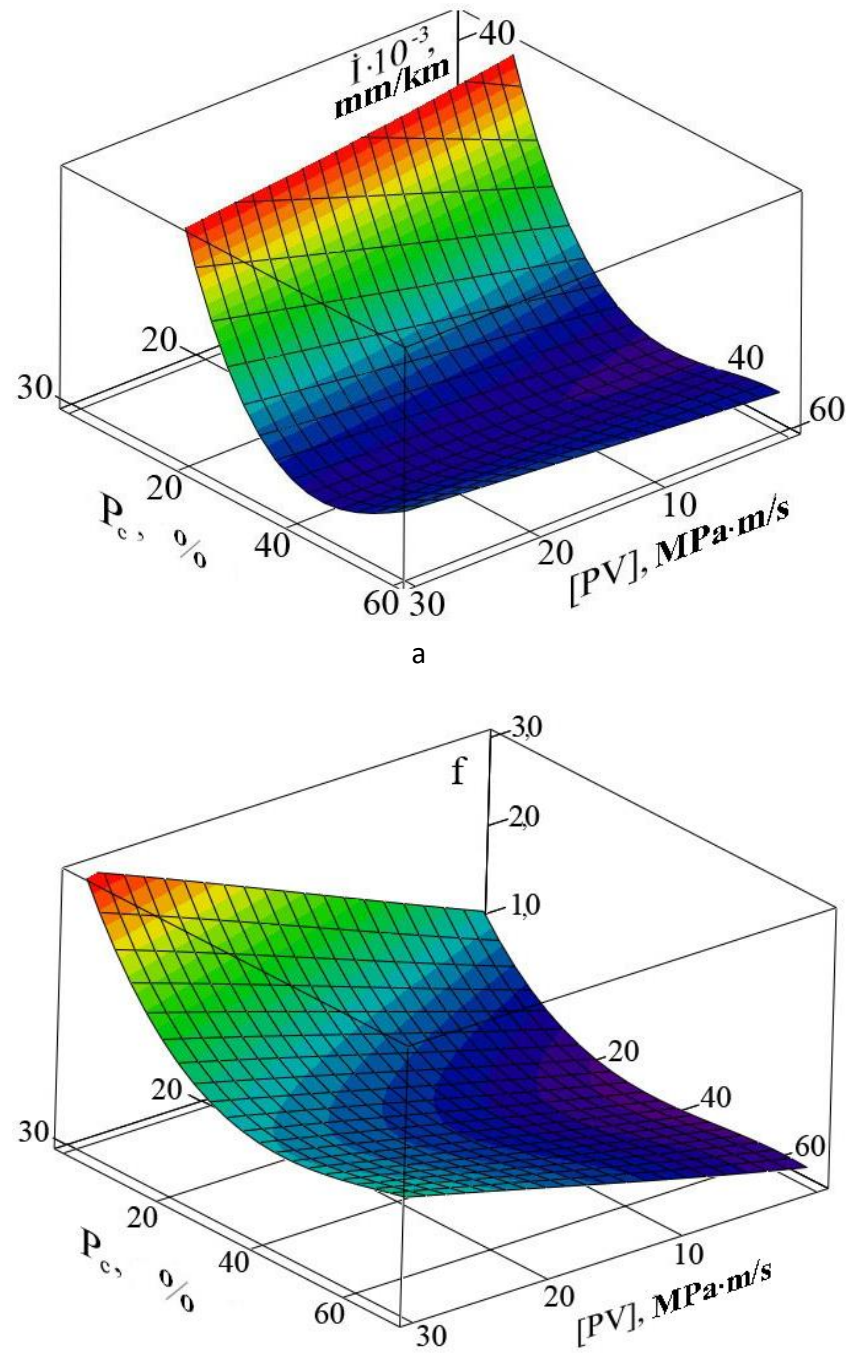

b

Figure 3. Dependencies of wear intensity (I) (a) and friction coefficient (f) (b) of BPU on exploitation parameter of usability [PV] and hard blocks content $\left(\mathbf{P}_{\mathrm{c}}\right)$ under conditions of friction in water

The change in roughness of the steel counterbody during the friction of polyurethanes with the content of hard blocks $20 \%$,
$50 \%$, and $70 \%$ was also studied. The initial roughness of steel counterbody was formed by grinding it on abrasive paper. The arithmetic average of absolute values of initial profile deviations $\mathrm{Ra}$ within the base length of $0.8 \mathrm{~mm}$ was equal to 1.0-0.85 $\mu \mathrm{m}$ (fig. 4, profilograms 1, 3, 6). For polyurethane with hard blocks concentration $\mathrm{P}_{\mathrm{c}}=20 \%$ the parameter $\mathrm{Ra}$ decreased to $0.59 \mu \mathrm{m}$ during the first kilometer of friction path. There is a somewhat smoothing of peaks radiuses of the microprotrusions of the counterbody profile from $0.05 \mu \mathrm{m}$ to $0.1 \mu \mathrm{m}$ on profilogram 2. The futher friction of BPU of a content of $\mathrm{P}_{\mathrm{c}}=20 \%$ occurred without noticeable changes in the roughness of the steel disk.

After $1 \mathrm{~km}$ of friction path of BPU with a content $\mathrm{P}_{\mathrm{c}}=50 \%$, its roughness decreased from $\mathrm{Ra}=1 \mu \mathrm{m}$ to $\mathrm{Ra}=0.58 \mu \mathrm{m}$, the profilogram 4 shows the smoothing of peaks radius of the microprotrusions from 0.05 to $0.1 \mu \mathrm{m}$. After $15 \mathrm{~km}$ of friction path, the roughness decreased to $\mathrm{Ra}=0.5 \mu \mathrm{m}$, and the radius at the peaks of the microprotrusions decreased to $0.5 \mu \mathrm{m}$ (profilogram 5). Further testing (more than $100 \mathrm{~km}$ of friction path) did not reveal any significant changes in the microgeometry of the friction surface of the steel counterbody, which indicates the establishment of equilibrium roughness with $\mathrm{Ra}=0.5 \mu \mathrm{m}$. Profilograms 7, 8 of the surfaces of steel counterbody during friction with $\mathrm{BPU}$ of concentration $\mathrm{P}_{\mathrm{c}}=70 \%$ after $1 \mathrm{~km}$ and $15 \mathrm{~km}$ of path corresponded to profilograms 4, 5 for friction of BPU with $\mathrm{P}_{\mathrm{c}}=50 \%$.

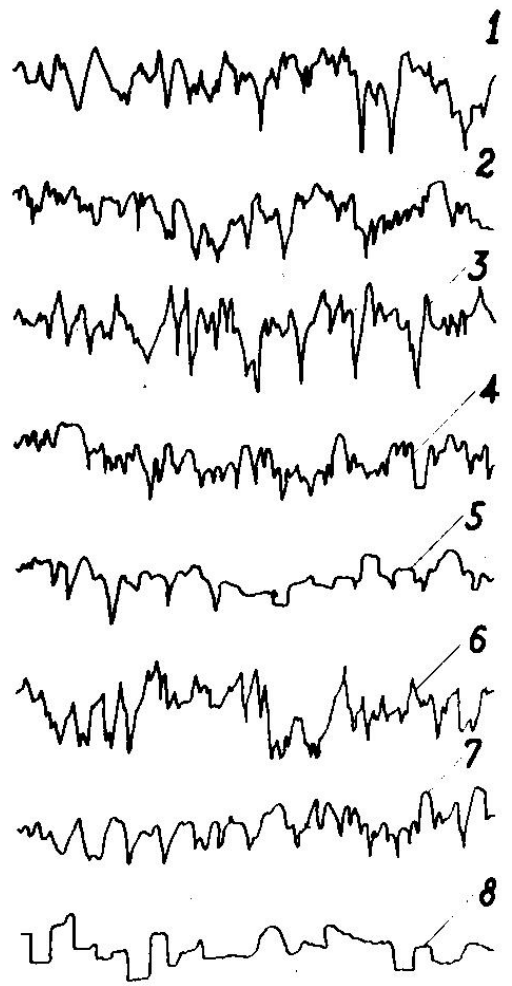

Figure 4. Profilograms of the steel counterbody surface (horizontal scale - 200, vertical scale - 10000):

1, 3, 6 -initial surface of the steel counterbody after grinding;

2 - surface after $1 \mathrm{~km}$ of friction path for polyurethanes of $P_{c}=20 \%$; 4 - surface after $1 \mathrm{~km}$ of friction path for polyurethanes of $P_{c}=50 \%$; 5 - surface after $15 \mathrm{~km}$ of friction path for polyurethanes of $P_{c}=50 \%$; 7 - surface after $1 \mathrm{~km}$ of friction path for polyurethanes of $\mathrm{P}_{\mathrm{c}}=70 \%$; 8 - surface after $15 \mathrm{~km}$ of friction path for polyurethanes of $\mathrm{P}_{c}=70 \%$.

However, noticeable longitudinal stripes and even scratches appeared on the counterbody, they are relatively evenly covering the entire surface, which indicates its wear during friction. A similar situation is observed after prolonged dynamic wear (more than $100 \mathrm{~km}$ of the friction path) of BPU with hard blocks content $70 \%$. Roughness $\mathrm{Ra}=0.5 \mu \mathrm{m}$ is maintained. 
Thus, when developing wear-resistant block-polyurethanes, in addition to the molecular and topological structure, their morphological structure must be taken into account. To improve wear resistance, accelerate initial lapping and create an optimal surface roughness, a method of coating products with BPU has been developed [Anisimov 2019]. In this way, finished BPU product (part) is placed in a container with an abrasive silicon powder of a particle size 5-30 $\mu \mathrm{m}$ and undergoes heat impact at $160-180 \stackrel{\circ}{ } \mathrm{C}$ for $60-80 \mathrm{~min}$. The usage of silicon carbide particles, which have a polarized covalent bond molecule, ensures their strong adhesion to the polymer surface. The application of a powder layer on the surface of the product occurs as a result of thermal diffusion of the particles to surface as well as due to their partial sticking. In the last case, due to the high adhesion, strength is quite high and particles do not crumble under friction, providing high lapping speed and wear resistance under operating conditions. Products from BPU, when processing in a given temperature range, do not lose their shape and do not deform. According to the results of the analysis of BPU samples with such a layer, under conditions of friction with the steel surface, the presence of abrasive powder allows to reduce the lapping time of metalpolymer pair more than in 10 times. Surfaces with same roughness are formed in the shortest time and increase wear resistance of the friction pair in 5-6 times. After the lapping process, in fact, friction occurs between the metal and original polyurethane material. The physico-mechanical characteristics remain at a high level.

Choosing of the optimum depth of penetration of silicon carbide powder particles into the surface layer is given in table. 2 , and the intensity of polyurethanes wearing with a surface layer saturated with abrasive particles of silicon carbide of different dispersion is given in table 3 . The given range of time and temperature regimes of processing is chosen due to the fact that at temperatures below $433 \mathrm{~K}$ and time less than 60 min the processes of thermodiffusion saturation were insignificant and no important impact on the material properties was found. At temperatures above $453 \mathrm{~K}$ and time more than 80 min some irreversible changes occurred in the material due to the processes of thermal degradation and the related processes of strength and deformation stability decreasing (table 2).

Table 2. Penetration depth of silicon carbide powder particles into the surface layer of polyurethane

\begin{tabular}{|c|c|c|c|c|c|c|c|c|}
\hline \multicolumn{4}{|c|}{$\begin{array}{l}\text { Average size of particles of } \\
\text { silicon carbide powder, } \mu \mathrm{m}\end{array}$} & 1 & 5 & 20 & 30 & 60 \\
\hline \multirow{20}{*}{ 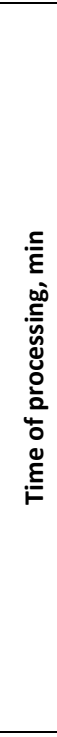 } & \multirow{5}{*}{40} & \multirow{20}{*}{ 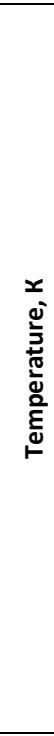 } & 413 & 0 & 0.5 & 4 & 4 & 11 \\
\hline & & & 433 & 0 & 0.5 & 5 & 7 & 15 \\
\hline & & & 443 & 0.35 & 1.5 & 5 & 12 & 20 \\
\hline & & & 453 & 0.5 & 2 & 6 & 13 & 20 \\
\hline & & & 463 & 0.35 & 2 & 6 & 15 & 20 \\
\hline & \multirow{5}{*}{60} & & 413 & 0 & 1.5 & 6 & 11 & 18 \\
\hline & & & 433 & 0.5 & 2 & 7 & 14 & 25 \\
\hline & & & 443 & 0.5 & 2.5 & 8 & 15 & 30 \\
\hline & & & 453 & 0.5 & 2.5 & 8 & 15 & 30 \\
\hline & & & 463 & 0.5 & 2.5 & 8 & 15 & 30 \\
\hline & \multirow{5}{*}{70} & & 413 & 0 & 1.5 & 6 & 11 & 18 \\
\hline & & & 433 & 0.5 & 2 & 7 & 14 & 25 \\
\hline & & & 443 & 0.5 & 2.5 & 8 & 15 & 30 \\
\hline & & & 453 & 0.5 & 2.5 & 8 & 15 & 30 \\
\hline & & & 463 & 0.5 & 2.5 & 8 & 15 & 30 \\
\hline & \multirow{5}{*}{80} & & 413 & 0 & 1.5 & 7 & 11 & 18 \\
\hline & & & 433 & 0.5 & 2 & 8 & 14 & 25 \\
\hline & & & 443 & 0.5 & 2.5 & 9 & 15 & 30 \\
\hline & & & 453 & 0.5 & 2.5 & 9 & 15 & 30 \\
\hline & & & 463 & 0.5 & 2.5 & 9 & 30 & 30 \\
\hline
\end{tabular}

\begin{tabular}{|l|l|l|l|l|l|l|l|l|}
\hline \multirow{3}{*}{100} & & 413 & 0.3 & 2 & 8 & 13 & 25 \\
\cline { 3 - 8 } & & 433 & 0.5 & 2.5 & 9 & 15 & 30 \\
\cline { 3 - 8 } & 443 & 0.5 & 2.5 & 9 & 15 & 30 \\
\cline { 3 - 8 } & & 453 & 0.5 & 2.5 & 9 & 15 & 30 \\
\cline { 3 - 8 } & & 463 & 0.5 & 2.5 & 9 & 15 & 30 \\
\hline
\end{tabular}

Data in table 2 shows, that the usage of silicon carbide powder fractions of a particle size about $5-30 \mu \mathrm{m}$ is optimal. The particles of larger sizes are poorly fixed in the surface layer of the material and quickly crumble in the process of friction. Such large particles occurrence in contact area leads to the appearance of liftings, splits on the surface and is accompanied by intensive material wear.

The saturation of the friction surface with silicon carbide particles of size less than 5 microns also does not produce significant positive results due to the intense crumbling under the influence of micro-roughness of the steel counter body.

The usage of proposed method for wear resistance increasing is recommended in the repair and mechanical shops (departments) of technological enterprises

Table 3. Intensity of wear of polyurethanes with a surface layer saturated with abrasive particles of silicon carbide

\begin{tabular}{|c|c|c|c|c|c|c|}
\hline \multirow[t]{6}{*}{ Indicator } & \multirow{6}{*}{$\begin{array}{c}\text { Initial } \\
\text { material* }\end{array}$} & \multicolumn{5}{|c|}{ Time of processing, $\min$} \\
\hline & & $\begin{array}{l}60- \\
80\end{array}$ & $\begin{array}{l}60- \\
80 \\
\end{array}$ & $\begin{array}{l}60- \\
80\end{array}$ & $\begin{array}{l}60- \\
80\end{array}$ & $60-80$ \\
\hline & & \multicolumn{5}{|c|}{ Temperature, $\mathrm{K}$} \\
\hline & & 453 & 453 & 453 & 453 & 453 \\
\hline & & \multicolumn{5}{|c|}{ Silicon carbide particles size, $\mu \mathrm{m}$} \\
\hline & & $1 * *$ & 5 & 20 & 30 & $60^{* * *}$ \\
\hline Lapping time, $\min$ & & - & 60 & 100 & 110 & - \\
\hline $\begin{array}{l}\text { Wear intensity } \\
\text { during friction } \\
\text { without } \\
\text { lubrication, } \\
\mathrm{mg} / \mathrm{km}: \\
-\quad \mathrm{BPU} \text { OEGA } \mathrm{A}_{2000} \\
\left(\mathrm{P}_{\mathrm{c}}=40 \text { mass } \%\right) \\
-\mathrm{BPU} \text { OEBGA } 2000 \\
\left(\mathrm{P}_{\mathrm{c}}=39 \text { mass } \%\right)\end{array}$ & $\begin{array}{l}2,5 \\
4,0\end{array}$ & $\begin{array}{l}2,5 \\
4,0\end{array}$ & $\begin{array}{c}0,25 \\
0,7\end{array}$ & $\begin{array}{l}0,3 \\
0,7\end{array}$ & $\begin{array}{l}0,4 \\
0,8\end{array}$ & $\begin{array}{c}9,0 \\
14,0\end{array}$ \\
\hline
\end{tabular}

Remarks:

$1-{ }^{*}$ Lapping time is compared to the full wear time of the applicated layer.

2 - ** The stage of lapping is absent. Due to the rapid crumbling of particles in the initial period, some friction is practically present between steel and the initial material.

$3-{ }^{* * *}$ The stage of lapping is absent. There are deep friction traces and tears (ruptures), that are likely for abrasive wear.

\section{CONCLUSIONS}

Estimation of the tribological characteristics of BPU depending on hardness, as suggested by ISO 16365-1:2014 P1, is inaccurate and requires further research to establish the relationship between the structure and properties of polyurethanes, taking into account their chemical structure and the type of initial components. The nature of the oligomer (oligoether, oligoester) is the most important in case of BPU workability estimation under conditions of light and thermooxidative degradation, high temperatures and humidity, resistance to the action of microorganisms. Taking into account 
the degree of crystallinity of both individual monomers and all the block material can let avoiding premature cracking and failure of polyurethane products during usage under severe dynamic conditions. The obtained dependences of wear intensity and coefficient of friction of the BPU on the sliding speed, specific load, temperature in the contact zone, amount of hard phase and antifriction filler showed that the influence of selected exploitation parameters and structural factors is decisive and should be taken into account when modeling the tribological parts. The analysis of the steel counterbody roughness during the friction of polyurethanes indicates the necessity to take into account their morphological structure. Proposed method of increasing wear resistance of BPU by the method of thermal diffusion saturation of the surface with silicon carbide particles can effectively control the lapping processes of the developed materials.

\section{ACKNOWLEDGMENTS}

This work was supported by the project VEGA 1/0205/19 of Scientific Grant Agency of the Ministry of Education, science, research and sport of the Slovak Republic and the Slovak Academy of Sciences.

The authors would like to thank the KEGA grant agency for supporting research work and co-financing the project KEGA: 004TUKE-4/2018.

\section{REFERENCES}

[Zia 2007] Zia, K.M., Bhatti, H.N., Ahmad Bhatti Methods for polyurethane and polyurethane composites, recycling and recovery: A review. Reactive and Functional Polymers. Volume 67, Issue 8, August 2007, pp. 675-692.

[Król 2007] Król, P. Synthesis methods, chemical structures and phase structures of linear polyurethanes. Properties and applications of linear polyurethanes in polyurethane elastomers, copolymers and ionomers. Progress in Materials Science. 2007, 52(6), pp. 915-1015.

[Chattopadhyay 2009] Chattopadhyay, D.K., Webster, D. Thermal stability and flame retardancy of polyurethanes. Progress in Polymer Science. 2009, 34(10), pp. 1068-1133.

[Shtompel 2011] Shtompel, V.I, Sasa, B.S, Polischuk, T.A, Ryabov, S.V. Structure of stoichiometric polyelectrolyte complexes based on Na-carboxymethyl cellulose and chitosan hydrochloride. Polymer Journal, 2011, 33(1), pp. 122-127.

[Madbouly 2009] Madbouly, S.A., Otaigbe, J.U. Recent advances in synthesis, characterization and rheological properties of polyurethanes and POSS/polyurethane nanocomposites dispersions and films. Progress in Polymer Science. 2009, 34(12), pp. 1283-1332.

[Thomas 2018] Thomas, S., Datta, J., Haponiuk, J., Reghunadhan, A. Polyurethane Polymers: Blends and Interpenetrating Polymer Networks 1st Edition. Elsevier, 2017, p. 442, ISBN: 9780128040393.

[Dyadyura 2016] Dyadyura K.A., Berladir K.V., Rudenko P.V., Budnik O.A., Sviderskij V.A. Research of properties of composite material based on polytetrafluoroethylene filled with carbon fiber with titanium nanocoating". In: International Conference on Nanomaterials: Application \& Properties (NAP) 2016, Sept. 14-19, 2016, Lviv, Ukraine.

[Panda 2017] Panda A., Dyadyura K., Valicek J., Harnicarova M., Zajac J., Modrak V., Pandova I., Vrabel P., NovakovaMarcincinova E.and Pavelek Z.: Manufacturing Technology of Composite Materials-Principles of Modification of Polymer
Composite Materials Technology Based on Polytetrafluoroethylene. Materials, 2017, 10 (4), pp. 337.

[Anisimov 2019] Anisimov, V.N., Anisimov, V.V., Krenicky, T. Properties prediction of linear block-polyurethanes based on the mixtures of simple oligoethers. Management Systems in Production Engineering. 2019. 27(4), pp. 217-220.

[Anisimov 2019] Anisimov, V.N., Anisimov, V.V. Technological features of processing linear Block-polyurethanes of different morphology. Voprosy khimii i khimicheskoi tekhnologii, 2019, No.4, pp. 5-11.

[ISO 16365-1:2014] ISO 16365-1:2014 Plastics - Thermoplastic polyurethanes for moulding and extrusion - Part 1: Designation sustem and basis for specifications: Designation system and basis for specifications

[Duplakova 2018] Duplakova, D. - Teliskova, M. - Duplak, J. Torok, J. - Hatala, M. - Steranka, J. - Radchenko, S.: Determination of optimal production process using scheduling and simulation software. International Journal of Simulation Modelling, 2018, 17 (4), pp. 447.

[Jurko 2016] Jurko, J.; Panda, A.; Valíček, J.; Harničárová, M.; Pandová, I. Study on cone roller bearing surface roughness improvement and the effect of surface roughness on tapered roller bearing service life. Int. J. Adv. Manuf. Tech., 82, p. 1099-1106.

[Monkova 2013] K. Monkova, P. Monka and D. Jakubeczyova, The research of the high speed steels produced by powder and casting metallurgy from the view of tool cutting life. In: Applied Mechanics and Materials, TTP, Switzerland, vol. 302, no. 302, 2013, p. 269-274.

[Gombar 2013] Gombár, M. - Vagaská, A. - Kmec, J. - Michal, Peter: Microhardness of the Coatings Created by Anodic Oxidation of Aluminium. In: Applied Mechanics and Materials, TTP, Zurich, Switzerland, vol. 308, 2013, p. 95-100.

[Mrkvica 2012] I. Mrkvica, M. Janos and P. Sysel, Contribution to milling of materials on $\mathrm{Ni}$ base. Applied Mechanics and Materials, Advanced Materials and Process Technology, vol. 217-219, 2012, p. 2056-2059.

[Leššo 2010] Leššo, I. - Flegner, P. - Šujanský, M. - Špak, E.: Researcg of the possibility of application of vector quantisation method for effective process control of rock desintegration by rotary drilling. Metalurgija, 2010, Vol. 49, No. 1, pp 61-65, ISSN 0543-5846

[Lesso 2014] Lesso, I. - Flegner, P. - Futo, J. -Sabova, Z.: Utilization of signal spaces for improvement of efficiency of metallurgical process. In: Metalurgija, 53 (1), 2014, p. 75-77, ISSN 0543-5846.

[Balara 2018] Balara, M., Duplakova, D., Matiskova, D. Application of a signal averaging device in robotics. In: Measurement. Vol. 115, No. 2, pp. 125-132, Issue 5-8, 2018, ISSN 0263-2241

[Krehel 2013] R. Krehel, L. Straka and T. Krenicky, Diagnostics of Production Systems Operation Based on Thermal Processes Evaluation. In: Applied Mechanics and Materials, Trans Tech Publications, Zurich, Switzerland, vol. 308, 2013, p.121-126.

[Krenicky 2012] T. Krenicky, M. Rimar, Monitoring of vibrations in the technology of AWJ. In: Key Engineering Materials. vol. 496, 2012, p. 229-234.

[Olejárová 2016] Olejárová, Štefánia - Krehel', Radoslav - Pollák, Martin - Kočiško, Marek: Research on impacts of mechanical vibrations on the production machine to its rate of change of technical state. In: Advances in mechanical engineering. Vol. 8, no. 7, 2016, p. 1-10. - ISSN 1687-8140. 
[Panda 2011] Panda, A. - Jurko, J. - Džupon, M. - Pandová, I.: Optimalization of heat treatment bearings rings with goal to eliminate deformation of material. Chem. Listy, 105, p. S459-S461.

[Pandová 2012] Pandová, I. - Gondova, T. - Dubayova, K.: Natural and modified clinoptilolite testing for reduction of harmful substance in manufacturing exploitation. In: Advanced Materials Research, 2012, Vol. 518-523, p. 1757-+, ISBN 978-303785-2416-7, ISSN 1022-6680.

[Panda 2013] Panda, A. - Duplak, J. - Jurko, J.: New experimental expression of durability dependence for ceramic cutting tool. In: Applied Mechanics and Materials, Trans Tech Publications, Zurich, Switzerland, vol. 275-277, 2013, p. 275277, ISSN 1660-9336.

[Prislupcak 2014] Prislupcak, M., - Panda, A. - Jancik, M. Pandova, I. - Orendac, P. - Krenicky, T.: Diagnostic and experimental valuation on progressive machining unit. In: Applied Mechanics and Materials, Trans Tech Publications, Zurich, Switzerland, vol. 616, 2014, p. 191-199, ISSN 1660-9336.

[Ragan 2012] Ragan, E., Dobransky, J., Baron, P., Kocisko, M., Svetlík, J. Dynamic of taking out molding parts at injection molding. Metallurgy No.4/2012, vol.51, Zagreb, Croatia, Croatian Metallurgical Society, 567-570 p.

[Rimar 2016] Rimar, M., Smeringai, P., Fedak M., Kuna S. Technical and software equipment for the real time positioning control system in mechatronic systems with pneumatic artificial muscles. In: Key Engineering Materials, Operation and Diagnostics of Machines and Production Systems Operational States 3. Vol. 669 (2016), p. 361-369. ISSN 1662-9795

[Vojtko 2014] I. Vojtko, V. Simkulet, P. Baron and I. Orlovsky, Microstructural Characteristics Investigation of the ChipMaking Process after Machining. In: Applied Mechanics and Materials, Trans Tech Publications, Zurich, Switzerland, vol. 616,2014 , p. 344-350, ISSN 1660-9336.

[Zaborowski 2007] Zaborowski, Ekowytwarzanie. Gorzow, pp. 100

[Straka 2013] L. Straka, I. Corný, I. - Krehel, R.: Evaluation of Capability of Measuring Device on the Basis of Diagnostics. In: Applied Mechanics and Materials, Trans Tech Publications, Zurich, Switzerland, vol. 308, 2013, p. 69-74.

[Straka 2014] Straka, L.: Operational reliability of mechatronic equipment based on pneumatic artificial muscle. In: Applied Mechanics and Materials, Trans Tech Publications, Zurich, Switzerland, vol. 2014, no. 460, p. 41-48, ISSN 1660-9336.

[Markulik 2016] Markulik, Š. - Kozel, R. - Šolc, M. - Pačaiová, $H .:$ Causal dependence of events under management system conditions. In: MM Science Journal, 2016, vol. 2016, Praha, Czech republic, Publisher: MM publishing Ltd., ISSN 1803-1269

[Michalik 2014] Zajac, J., Hatala, M., Mital, D. and Fecova, V. Monitoring surface roughness of thin-walled components from steel C45 machining down and up milling. In: Measurement, vol. 58, 2014, p. 416-428, ISSN 0263-2241.
[Janekova 2014] J. Janekova, J. Kovac and D. Onofrejova, Modelling of Production Lines for Mass Production of Sanitary Products. Elsevier, Netherlands. In: Procedia Engineering, Elsevier, vol. 2014, no. 96, 2014, p. 330-337.

[Sebo 2012] Sebo, J. - Svetlik, J. - Fedorcakova, M. and Dobransky,,J.: The comparison of performance and average costs of robotic and human based work station for dismantling processes. In: Acta Technica Corviniensis: Bulletin of engineering, vol. 5, no. 4, 2012, p. 67-70, ISSN 2067-3809.

[Jurko 2012] Jurko, J. - Džupon, M. - Panda, A. - Zajac, J.: Study influence of plastic deformation a new extra low carbon stainless steels XCr17Ni7MoTiN under the surface finish when drilling.. In: Advanced Materials Research, 2012, AEMT 2012, Vol. 538-541, p. 1312-1315, ISBN 978-3-03785-447-1, ISSN 1022-6680.

[Valíček 2016] Valíček, J. - Harničárová, M. - Panda, A. - Hlavatý, I. - Kušnerová, M. - Tozan, H. - Yagimli, M. - Václavík, V.: Mechanism of Creating the Topography of an Abrasive Water Jet Cut Surface.In: Machining, joining and modifications of advanced materials. In: Advanced Structured Materials, Singapore, Springer Verlag, 2016 Vol. 61, p. 111-120, ISBN 978981-10-1082-8, ISSN 1869-8433.

[Panda 2018] Panda, A. - Olejárová, Š. - Valíček, J. Harničárová, M.: Monitoring of the condition of turning machine bearing housing through vibrations.In: The International Journal of Advanced Manufacturing Technology, 2018, Vol. 97, no. 1-4 , p. 401-411, ISSN 0268-3768.

[Bielousová 2017] Bielousová, R.: Developing materials for english for specific purposes online course within the blended learning concept. In: TEM Journal, Vol. 2017, no. 3 (2017), p. 637-642, ISSN 2217-8309.

[Dobránsky 2019] Dobránsky, J. - Polllák, M. - Doboš, Z.: Assessment of production process capability in the serial production of components for the automotive industry. In: Management systems in production engineering, 2019, Vol. 27, no. 4, p. 255-258, ISSN 2299-0461.

[Pollák 2018] Polllák, M. - Török, J. - Zajac, J. - Kočiško, M. Telišková, M.: The structural design of $3 D$ print head and execution of printing via the robotic arm ABB IRB 140. In: ICIEA 2018, Danvers, IEEE, p. 194-198, ISBN 978-153865747-8.

[Panda 2012] Panda, A. - Duplak, J. - Jurko, J. - Behun, M.: Comprehensive identification of sintered carbide durability in machining process of bearings steel 100CrMn6. In: Advanced Materials Research, 2012, AEMT 2012, Vol. 340, p. 30, ISBN 978-3-03785-253-8, ISSN 1022-6680.

[MACALA 2012] Mačala, J. - Pandová, I. - Gondova, T. Dubayova, K.: Reduction of polycyclic aromatic hydrocarbons and nitrogen monoxide in combustion engine exhaust gases by clinoptilolite. In: Gospodarka surowcami mineralnymi-Mineral resources management, 2012, Vol. 28, Issue 2, p. 113-123, ISSN 0860-0953.

\section{CONTACTS:}

Prof. Eng. Anton Panda, PhD.

Faculty of Manufacturing Technologies with a seat in Prešov,

Technical University of Kosice, Slovakia

Sturova 31, 080001 Presov, Slovakia

e-mail: anton.panda@tuke.sk 